\title{
A FAMILIAL HEMORRHAGIC TRAIT ASSOCIATED WITH A DEFICIENCY OF A CLOT-PROMOTING FRACTION OF PLASMA ${ }^{1}$
}

\author{
BY OSCAR D. RATNOFF AND JOAN E. COLOPY
}

\author{
(From the Department of Medicine, the Western Reserve University School of Medicine, \\ and University Hospitals, Cleveland, Ohio)
}

(Submitted for publication October 11, 1954 ; accepted December 29, 1954)

Recently, three patients have been studied in whom the clotting time of venous blood was greatly prolonged. None of the patients had significant hemorrhagic symptoms. The trait was apparently familial and appeared in both sexes. The patients' disorder could not be identified with any known bleeding disease. However, in each case, the plasma was deficient in a substance found in normal globulin which accelerated the clotting of normal, platelet-deficient plasma.

This clot-promoting fraction, present in heated, barium sulfate-adsorbed serum, was neither thrombic nor thromboplastic and did not alter the rate of conversion of fibrinogen to fibrin by thrombin, nor of prothrombin to thrombin by tissue thromboplastin. By inference, its effect was upon an earlier stage of clotting, presumably upon the development of thromboplastic activity in shed blood. However, the fraction did not appear to contain any of the components of plasma known to be necessary for the optimal evolution of plasma thromboplastic activity. The characteristics of the clot-promoting fraction, deficient in the plasma of these three patients, suggests that its properties may be identical with those of an unidentified accelerator of clotting described in an earlier study (1). Tentatively, until its mode of action becomes clear, this fraction may be named Hageman factor, after Patient I.

\section{CASE REPORTS}

I. J. R. H. (Crile V.A.H. No. 65930), a 37-year-old railroad brakeman, was first studied during July, 1953, because a prolonged clotting time was observed during routine pre-operative studies. He had no history of hemorrhagic difficulties, purpura or anemia, and had not

1 This study was supported in part by a research grant (P.H.S. No. H1661C) from the National Heart Institute of the National Institutes of Health, Public Health Service, and in part by a grant from the Cleveland Area Heart Society. bled after a tonsillectomy when he was 6 years old, after an injury to the hand at 10 , nor after a dental extraction, at 36. He had had symptoms and laboratory evidence of a duodenal ulcer since 1943, and was to be operated upon for the relief of pyloric obstruction, but this procedure was not carried out because of the abnormal clotting time. A few months before he was studied, he had had black stools for 2 days, but he was taking bismuth orally at the time. There was no familial history of bleeding, and, to his knowledge, the patient was unrelated to Patients II and III. His platelet count, clot retraction, and bleeding time were, normal for the methods used. A tourniquet test was strongly positive. Innumerable petechiae appeared on the forearm below a blood pressure cuff inflated at $100 \mathrm{~mm}$. $\mathrm{Hg}$ pressure for 5 minutes.

II. M. R., a 46-year-old housewife, was first studied during July, 1954, because of a prolonged clotting time. She first learned that her clotting time was abnormal in 1938, when a right salpingo-oophorectomy was postponed for 2 hours on this account. The operation was performed without difficulty. She had no history of hemorrhagic symptoms, menorrhagia or abnormal bleeding at the birth of her son in 1936 and had no abnormal bleeding after an appendectomy at 30 years of age, a hemorrhoidectomy at 31 , nor several dental extractions. $\mathrm{Pa}$ tient III is one of this patient's two surviving sisters. Five other relatives, including the son of Patient II and her third sister, do not have an abnormal clotting time. The patient had severe varicose veins and a few tiny ecchymotic spots on her legs. The platelet count, clot retraction and bleeding time were all normal. The tourniquet test was equivocal. About 50 petechiae appeared in an area under the cuff, about 50 at the crease of the elbow, and 6 in an area the size of a silver dollar on the volar surface of the forearm, after a blood pressure cuff was inflated at $100 \mathrm{~mm}$. $\mathrm{Hg}$ for 5 minutes. By electrophoretic analysis, her plasma contained 3.44 grams of albumin, 0.40 grams of alpha globulin, 0.68 grams of beta globulin, 0.72 grams of gamma globulin, and 0.35 grams of fibrinogen-like material per $100 \mathrm{ml}$.

III. T. $R$., a 50-year-old housewife, was studied in July, 1954, in a survey of members of the family of $\mathrm{Pa}$ tient II. She had never had any symptoms suggestive of a bleeding tendency, and was delivered of 4 daughters, had several dental extractions and a minor operation upon her breast, all without difficulty. As a child, one of the patient's daughters had nosebleeds, and this child's 
daughter, now 6, also has nosebleeds, but neither of these two individuals has the coagulative defect.

\section{MATERIALS}

Blood was drawn from the antecubital veins of the patients and of normal human adults, using No. 18 gauge needles coated with tris (2-hydroxyethyl)dodecyl-ammonium chloride (Armour Needle Coating Solution) and glass syringes coated with silicone (Desicote, Beckman).

Oxalated plasma was prepared by mixing nine parts of venous blood with one part of $0.1 \mathrm{M}$ sodium oxalate solution, and removing the cells by centrifugation at $2500 \mathrm{rpm}$ for 15 minutes at room temperature in an International SB Size 1 centrifuge. This plasma was kept in ice water and used within a few hours, or stored at $4^{\circ} \mathrm{C}$. or $-27^{\circ} \mathrm{C}$. for as long as a year until used.

Platelet-deficient "native" plasma was prepared without the addition of an anticoagulant by the method of Conley, Hartmann, and Morse (2). Venous blood was centrifuged at $10,500 \mathrm{rpm}(14,000 \mathrm{G})$ for 10 minutes in silicone-coated lusteroid tubes, in a Servall SS-1 angle centrifuge refrigerated at $-5^{\circ} \mathrm{C}$. The upper portion of the plasma was removed with a silicone-coated pipette and kept until used in silicone-coated lusteroid tubes immersed in ice water. Such native plasma contained less than 50 platelets per $\mathrm{mm}^{.}$, and, rarely, a few erythrocytes.

Lipid-deficient serum was prepared at $4^{\circ} \mathrm{C}$. by adding $10 \mathrm{ml}$. of pooled human serum drop-wise to $200 \mathrm{ml}$. or more of a mixture of 2 parts of chloroform and 1 part of absolute methyl alcohol, in the Monel metal cup of a Waring blender rotating at moderate speed. The mixture was filtered through Whatman No. 1 filter paper in a Büchner funnel. The residue on the paper was dried at $4^{\circ} \mathrm{C}$. in a desiccator containing concentrated sulfuric acid and soda-lime, using suction, and then ground with buffer in a volume equal to that of the original serum, using a mortar and pestle. Remnants of paper were removed by centrifugation at $10,500 \mathrm{rpm}$ for 3 minutes in a Servall SS-1 centrifuge at $-5^{\circ} \mathrm{C}$. The supernatant solution of lipid-deficient serum had about half the concentration of protein of the original serum.

Barium sulfate-adsorbed plasma or serum was prepared by incubating a mixture of oxalated plasma or serum and one-tenth volume of powdered barium sulfate (Baker) at $37^{\circ} \mathrm{C}$. for 10 minutes, stirring occasionally. The adsorbed plasma or serum was then separated by centrifugation. Adsorbed plasma was presumably deficient in prothrombin, proconvertin and plasma thromboplastin component. Adsorbed serum lacked, in addition, fibrinogen, proaccelerin and anti-hemophilic factor.

A globulin fraction of plasma or serum was prepared by dilution with water and acidification to approximately pH 5.3. In some experiments, this crude globulin was prepared from native plasma in silicone-coated glassware in such a manner that at no time did it come in contact with an anticoagulant or with a glass or metal surface
(3). The precipitated globulin was dissolved in buffer, usually in a volume equal to that of the original sample of plasma. Such native plasma globulin is known to contain many substances, including prothrombin, fibrinogen, proaccelerin, proconvertin, anti-hemophilic factor, plasma thromboplastin component, and small amounts of calcium (3), as well as an unidentified accelerator of clotting described previously (1).

In other experiments, the globulin fraction of serum or of oxalated plasma was prepared in Pyrex tubes by dilution of the sample with 19 volumes of water and acidification to approximately $\mathrm{pH}$ 5.3. When the sample was $1.0 \mathrm{ml}$. in volume or larger, one per cent acetic acid was used. When samples of $0.1 \mathrm{ml}$. of oxalated plasma were used, the acidification was arbitrarily performed by the addition of $0.1 \mathrm{ml}$. of 0.25 per cent acetic acid. The globulin thus prepared was separated by centrifugation at room temperature for 15 minutes at $2500 \mathrm{rpm}$ and dissolving the precipitate in buffer.

Further fractionation of the globulin was performed by precipitation with ammonium sulfate. The globulin was concentrated either 2 or 4 times compared with the original plasma or serum. The globulin solution was diluted with ammonium sulfate solution which was saturated at $4^{\circ} \mathrm{C}$. and neutralized with concentrated ammonium hydroxide. Successive fractions were prepared by the addition of sufficient ammonium sulfate solution to raise the concentration to the desired degree of saturation. Each mixture was refrigerated at $4^{\circ} \mathrm{C}$. for 24 hours and the precipitate separated by centrifugation at room temperature. The precipitates were dissolved in water, reprecipitated by ammonium sulfate for 24 hours and recentrifuged. The precipitates were then dissolved in water and dialyzed in Visking No-Jax cellophane casings, first against running tap water and then against frequent changes of buffer. The supernatant fluid remaining after halfsaturation with ammonium sulfate was dialyzed in the same way. The fraction precipitated between 33 and 50 per cent saturation with ammonium sulfate from the globulin of serum which had been stored at $4^{\circ} \mathrm{C}$. for 6 weeks and then adsorbed with barium sulfate and heated at $56^{\circ} \mathrm{C}$. for 30 minutes will be designated the clotpromoting fraction. However other fractions also possess considerable clot-promoting activity; the method described was not designed to result in a maximal yield.

Platelets were prepared from Patient I's blood by mixing $10 \mathrm{ml}$. of blood with $0.3 \mathrm{ml}$. of 5 per cent sequestrene $\mathrm{Na} 2$ in a silicone-coated centrifuge tube. ${ }^{2}$ The blood was centrifuged for 20 minutes at $800 \mathrm{rpm}$ in an International SB Size 1 centrifuge. The platelet-rich plasma was then recentrifuged at $2500 \mathrm{rpm}$ for 15 minutes. The platelets were suspended in $5 \mathrm{ml}$. of $0.15 \mathrm{M}$ sodium chloride solution and recentrifuged, a total of three times, and finally suspended in $2 \mathrm{ml}$. of sodium chloride solution.

The buffer solution consisted of 7.30 grams of sodium chloride, 2.76 grams of barbital and 2.06 grams of sodium barbital, diluted to a volume of 1 liter with distilled

\footnotetext{
2 Sequestrene $\mathrm{Na} 2$ was provided through the courtesy of the Alrose Chemical Company, Providence.
} 
water. The buffer was thus composed of $0.025 \mathrm{M}$ barbital and $0.125 \mathrm{M}$ sodium chloride, at $\mathrm{pH}$ 7.5.

\section{METHODS}

The clotting time of whole blood was measured by a modification of the method of Lee and White (4), using dry Pyrex or silicone-coated tubes (internal diameter, $11 \mathrm{~mm}$.) (5). In 107 normal individuals, the clotting time at $25^{\circ} \mathrm{C}$. in Pyrex tubes averaged 32.1 minutes (range, 11 to 56 ; standard deviation of the mean, 9.0 minutes). In silicone-coated tubes, the clotting time in 72 normal persons averaged 98.6 minutes (range, 55 to 165 ; standard deviation of the mean, 19.2 minutes).

The recalcified clotting time of oxalated plasma was determined, usually at $25^{\circ} \mathrm{C}$., in Pyrex tubes (internal diameter, $8 \mathrm{~mm}$.). In duplicate, $0.2 \mathrm{ml}$. of plasma and $0.2 \mathrm{ml}$. of $0.025 \mathrm{M}$ calcium chloride solution were mixed in tubes immersed in ice water and then rapidly transferred to a water bath at $25^{\circ} \mathrm{C}$. The clotting time was determined by tilting both tubes at 15 - or 20 -second intervals. After 20 or 30 minutes, the tubes were observed at progressively longer intervals. The clotting time was the period which elapsed from the time that the tubes were transferred to the $25^{\circ} \mathrm{C}$. bath until the appearance of a solid clot. The longer of the duplicate clotting times is recorded. However, it is noteworthy that the contents of the duplicate tubes almost always coagulated within 30 seconds of each other when the clotting time was 12 minutes or less. In 63 normal subjects, the recalcified clotting time at $25^{\circ} \mathrm{C}$. averaged 6.9 minutes (range, 3 to 12 ; standard deviation, 2.0 minutes).

The clotting time of native plasma was measured at $37^{\circ} \mathrm{C}$. by transferring $1 \mathrm{ml}$. of plasma to each of $3 \mathrm{Py}-$ rex and 3 silicone-coated tubes (internal diameter, 11 mm.). The tubes were closed with rubber stoppers and incubated in a water bath. The clotting time was determined in the same manner as that of whole blood (5). Native plasma obtained from normal individuals usually clots in 60 minutes or less in Pyrex tubes (2). In silicone-coated tubes, the clotting time is much longer, and normal plasma may not clot at all (2).

The clotting time of native plasma was also tested in Pyrex tubes containing weighed amounts of crushed Pyrex glass (50 to 100 mesh), which had been washed with chromic acid and thoroughly rinsed with distilled water.

The conditions under which the effect of various substances upon the clotting time of whole blood, recalcified oxalated plasma, or native plasma were tested will be described with each experiment. In general, all mixtures were prepared in tubes immersed in mixtures of ice and water, and then transferred to water baths at 25 or $37^{\circ} \mathrm{C}$.

The possible presence of a circulating anticoagulant was tested in native plasma by the method of Conley, Hartmann, and Morse ( 6 ), and in oxalated plasma, by measuring the recalcified clotting time of suitable mixtures of the patient's plasma and normal plasma.

The thrombin time, that is, the clotting time of an equal mixture of oxalated plasma and bovine thrombin (Parke, Davis and Co.) was determined at $37^{\circ} \mathrm{C}$. in Pyrex tubes (internal diameter, $8 \mathrm{~mm}$.) (7). The results were interpolated relative to a standard thrombin time, for normal individuals, of $\mathbf{3 0}$ seconds. In any given normal adult, the thrombin time rarely varied by more than 3 seconds from that of any other normal adult (7).

The prothrombin time was determined at $37^{\circ} \mathrm{C}$. by a one-stage method (8), mixing $0.1 \mathrm{ml}$. of oxalated plasma, $0.1 \mathrm{ml}$. of rabbit or human brain thromboplastin or Russell Viper Venom, and $0.1 \mathrm{ml}$. of $0.025 \mathrm{M}$ calcium chloride solution in Pyrex tubes (internal diameter, $8 \mathrm{~mm}$.). Human or rabbit brain thromboplastin (Cappell Laboratories, Wayne, $\mathrm{Pa}$.) was prepared by suspending $150 \mathrm{mg}$. in $4 \mathrm{ml}$. of $0.15 \mathrm{M}$ sodium chloride solution and $0.05 \mathrm{ml}$. of $0.1 \mathrm{M}$ sodium oxalate solution, and heating the mixture between 45 and $50^{\circ} \mathrm{C}$. for 15 minutes. Rabbit brain thromboplastin (Difco Laboratories, Detroit) was suspended without the addition of oxalate and heated for only 10 minutes. Russell Viper Venom (Stypven, Burroughs, Wellcome) ${ }^{3}$ was dissolved in a concentration of 0.01 per cent in water. The suspensions of thromboplastin described will be referred to as "undiluted."

A more specific test for prothrombin was performed by Alexander's modification (9) of the method of Owren and Aas (10) in which the concentration of prothrombin is determined in the presence of proaccelerin and proconvertin. The proaccelerin and proconvertin were provided by an equal mixture of barium sulfate-adsorbed bovine plasma and of pooled human serum which had been decalcified with sodium oxalate after storage at $4^{\circ} \mathrm{C}$. for 4 months.

The two-stage prothrombin method of Ware and Seegers (11) was used, employing Difco reagents and bovine fibrinogen solution.* The fibrinogen solution was prepared by dissolving $150 \mathrm{mg}$. of dried materials (12) in $10 \mathrm{ml}$. of 0.70 per cent sodium chloride solution. The resultant solution, after filtration through Whatman No. 1 paper, contained about one per cent coagulable protein in $\mathbf{0 . 8 5}$ per cent sodium chloride solution.

The serum prothrombic activity was measured by allowing $2.25 \mathrm{ml}$. of blood to clot at $37^{\circ} \mathrm{C}$. in a Pyrex tube (internal diameter, $8 \mathrm{~mm}$.). One hour after the blood was drawn, a volume of $0.25 \mathrm{ml}$. of $0.1 \mathrm{M}$ sodium oxalate solution was added, the contents thoroughly mixed with a wooden applicator stick, and the mixture centrifuged at room temperature for 15 minutes at $2500 \mathrm{rpm}$ in the International centrifuge. The oxalated serum was then heated at $37^{\circ} \mathrm{C}$. for 30 minutes to destroy any remaining free thrombin. Heating for shorter periods was not adequate for this purpose. The prothrombic activities of the patient's serum and oxalated plasma were then compared using the specific prothrombin method. This test gave somewhat erratic results, but in 46 normal

\footnotetext{
8 Stypven was provided through the courtesy of Burroughs, Wellcome and Company, New York.

- Dr. Walter Seegers, Detroit, kindly provided the preparation of purified bovine fibrinogen.
} 
TABLE I

The clotting time, thrombin time and plasma prothrombic activity in three patients

\begin{tabular}{|c|c|c|c|c|}
\hline Test & Case I & Case II & Case III & $\underset{\text { range }}{\text { Normal }}$ \\
\hline $\begin{array}{l}\text { Clotting time, } 25^{\circ} \mathrm{C} . \text {, whole blood (min.) } \\
\text { Pyrex tubes } \\
\text { Silicone-coated tubes } \\
\text { Clotting time, } 37^{\circ} \mathrm{C} \text {., native plasma (min.) } \\
\text { Clotting time, } 25^{\circ} \mathrm{C} \text {., recalcified plasma (min.) } \\
\text { Thrombin time (sec.; control = } 30 \text { seconds) } \\
\text { Plasma prothrombic activity (sec.; one-stage method*) } \\
\text { Patient } \\
\text { Control }\end{array}$ & $\begin{array}{c}87 \\
300 \\
\infty \\
102 \\
28 \\
14 \\
13\end{array}$ & $\begin{array}{r}86 \\
330 \\
\infty \\
47 \\
30 \\
17 \\
17\end{array}$ & $\begin{array}{r}90 \\
300 \\
\overline{47} \\
- \\
-\end{array}$ & $\begin{array}{r}11-56 \\
55-165 \\
<60 \\
3-12 \\
27-33 \\
- \\
-\end{array}$ \\
\hline
\end{tabular}

* Rabbit brain thromboplastin.

individuals, the serum prothrombic activity, one hour after blood was drawn, was 40 per cent or less in 44 instances, 35 per cent or less in 42 instances, and 30 per cent or less in 38 instances.

The effect of trypsin on oxalated plasma was tested in Pyrex tubes (internal diameter, $8 \mathrm{~mm}$.) by mixing 0.2 $\mathrm{ml}$. of plasma and $0.1 \mathrm{ml}$. of aqueous trypsin solution (Worthington Chemical Co.). The trypsin solution consisted of $0.8 \mathrm{mg}$. of dried material per $\mathrm{ml}$. of water; the dried preparation contained as much as 50 per cent magnesium sulfate.

The presence of staphylocoagulase-reacting factor in oxalated plasma was tested by the slide method of Cadness-Graves, Williams, Harper, and Miles (13), using a 24-hour culture on tryptose blood agar base of a strain of micrococcus staphylococcus var. aureus known to be coagulase positive.

The presence of plasminogen (the precursor of plasmin, the proteolytic enzyme or enzymes of plasma maximally active against most substrates at neutrality) was tested in oxalated plasma by the addition of $0.1 \mathrm{ml}$. of a solution of streptokinase-streptodornase, containing 600 Christensen units (14) of streptokinase ${ }^{5}$ per $\mathrm{ml}$. of water, to $0.2 \mathrm{ml}$. of plasma in Pyrex tubes (internal diameter, $8 \mathrm{~mm}$.). The mixture was clotted by the addition of $0.1 \mathrm{ml}$. of bovine thrombin solution (Parke, Davis and Co.) containing $10 \mathrm{National}$ Institutes of Health (N.I.H.) units (15) per ml. of buffer. The clot lysis time was then measured at $37^{\circ} \mathrm{C}$.

The presence of plasminogen in the clot-promoting fraction of serum was tested in Pyrex tubes by mixing $0.3 \mathrm{ml}$. of the fraction, $0.3 \mathrm{ml}$. of streptokinase solution (100 units per $\mathrm{ml}$.), $0.3 \mathrm{ml}$. of bovine fibrinogen solution (one per cent coagulable protein) and $0.1 \mathrm{ml}$. of bovine thrombin solution ( 10 N.I.H. units per ml.). The clot lysis time was then measured at $37^{\circ} \mathrm{C}$. and compared with the lysis time of the same mixture in which buffer was substituted for streptokinase or for the fraction.

5 Varidase a commercial preparation of streptokinase and streptodornase, was provided through the courtesy of Lederle Laboratories, Pearl River, New York.
RESULTS

\section{The nature of the clotting defect}

In each of the three cases the clotting time of whole blood at $25^{\circ} \mathrm{C}$. was prolonged both in glass and in silicone-coated tubes (Table I). This may have been due to a cellular or plasma defect. To test this, the clotting time of native, cell-free plasma from Patients I and II was measured in Pyrex tubes. Normally, the clotting time of such cell-free plasma is about that of whole blood (2). In these cases, however, native plasma was incoagulable (Table I). One must conclude that the defect was in the plasma.

The platelet-free plasma, however, was not totally incoagulable. In duplicate, one $\mathrm{ml}$. of plasma of Patient I was pipetted into Pyrex tubes containing crushed Pyrex glass. The clotting time at $37^{\circ} \mathrm{C}$. was 182 minutes in the presence of $100 \mathrm{mg}$. of glass and 144 minutes in the presence of $500 \mathrm{mg}$. of glass. The platelet-deficient plasma also clotted when it was diluted with $0.15 \mathrm{M}$ sodium chloride solution (Table II). The minimum clotting time was noted in a mixture of 60

TABLE II

The effect of dilution on the clotting time of platelet-deficient plasma

\begin{tabular}{cc}
\hline \hline Per cent plasma & Clotting time* \\
\hline & $\operatorname{min.}$ \\
100 & $\infty$ \\
80 & 280 \\
60 & 113 \\
40 & 144 \\
20 & $\infty$
\end{tabular}

* Clotting time in duplicate of mixtures of Patient I's platelet-deficient native plasma and $0.15 \mathrm{M}$ sodium chloride solution, in Pyrex tubes (internal diameter $11 \mathrm{~mm}$.) at $37^{\circ} \mathrm{C}$. 
per cent plasma and 40 per cent sodium chloride solution.

The recalcified clotting time was greatly prolonged in each instance. The plasmas from $\mathrm{Pa}$ tients I and II were not mutually corrective. In one experiment the recalcified clotting time in Case I exceeded 60 minutes, and in Case II was 30 minutes. An equal mixture of the two clotted in 41 minutes. Further evidence for the identity of the defect in all three cases will be presented subsequently.

Cases have been described in which a prolonged clotting time was attributed to a circulating anticoagulant. None could be demonstrated in native plasma, in Case I, nor in oxalated plasma, in all three cases. For example, the recalcified clotting time in Case II was 51 minutes, and that of a normal plasma, was 5 minutes. A mixture of 80 parts of the patient's plasma and only one part of normal plasma clotted in ten minutes. Other experiments to be described confirm the probable absence of a circulating anticoagulant.

An attempt was made to determine whether the patients' clotting abnormality could be classified among known disorders of blood clotting. The thrombin time and one-stage prothrombin time were normal in Cases I and II (Table I). Furthermore, the prothrombin time was normal whether one used tissue thromboplastin from human or rabbit brain, whether either preparation was undiluted or diluted $1: 100$ with $0.15 \mathrm{M}$ sodium chloride solution; or whether one used Russell Viper Venom as a thromboplastin. On the other hand, a suspension of platelets did not have an impressive clot-accelerating effect (Table III). In Case II, the plasma prothrombic activity, by

TABLE III

The effect of a platelet suspension upon the recalcified clotting time

\begin{tabular}{ccc}
\hline \hline & \multicolumn{2}{c}{ Clotting time* } \\
\cline { 2 - 3 } Plasma & Platelets & Buffer \\
\hline Patient I & min. & min. \\
Control & 42 & 74 \\
& 4 & 8
\end{tabular}

* Clotting time in duplicate of a mixture of $0.2 \mathrm{ml}$. of oxalated plasma, $0.1 \mathrm{ml}$. of platelet suspension or buffer, and $0.2 \mathrm{ml}$. of $0.025 \mathrm{M}$ calcium chloride solution, at $25^{\circ} \mathrm{C}$. in Pyrex tubes (internal diameter, $8 \mathrm{~mm}$.). The platelets were derived from Patient I's blood and were in a volume of buffer one-fifth that of the original blood sample.
TABLE IV

Effect of plasmas from patients with known hemorrhagic disorders upon the recalcified clotting time

\begin{tabular}{|c|c|}
\hline Plasma & $\underset{\text { time* }}{\text { Clotting }}$ \\
\hline $\begin{array}{l}\text { A. Patient I, } 0.2 \mathrm{ml} . \\
\text { Patient II, } 0.2 \mathrm{ml} . \\
\text { Patient I, } 0.1 \mathrm{ml} .+ \text { Patient II, } 0.1 \mathrm{ml} .\end{array}$ & $\begin{array}{l}\min . \\
60 \\
47 \\
60\end{array}$ \\
\hline $\begin{array}{l}\text { B. Patient I, } 0.1 \mathrm{ml} .+ \text { Buffer } 0.1 \mathrm{ml} \text {. } \\
\text { Patient I, } 0.1 \mathrm{ml} \text {. Normal plasma } \\
\text { (diluted } 1 / 160 \text { ) } 0.1 \mathrm{ml} \text {. } \\
\text { Patient I, } 0.1 \mathrm{ml} \text {. }+ \text { Hemophilic plasma } \\
\text { (diluted } 1 / 160 \text { ) } 0.1 \mathrm{ml} \text {. } \\
\text { Patient I, } 0.1 \mathrm{ml} \text {. Christmas disease } \\
\text { (diluted } 1 / 160 \text { ) } 0.1 \mathrm{ml} \text {. } \\
\text { Patient I, } 0.1 \mathrm{ml} \text {. + Plasma deficient in 4th } \\
\text { thromboplastin component (diluted } 1 / 160 \text { ) } \\
0.1 \mathrm{ml} \text {. }\end{array}$ & $\begin{array}{c}60 \\
12 \\
11 \\
10\end{array}$ \\
\hline $\begin{array}{l}\text { C. Patient I, 0.1 ml. + Buffer } 0.1 \mathrm{ml} \text {. } \\
\text { Patient I, 0.1 ml. + Normal plasma } \\
\text { (diluted 1/80) 0.1 ml. } \\
\text { Patient I, 0.1 ml. + Patient II's plasma } \\
\text { (diluted 1/80) 0.1 ml. } \\
\text { Patient I, 0.1 ml. + Plasma "A.A." deficient } \\
\text { in plasma thromboplastin antecedent } \\
\text { (diluted 1/80) 0.1 ml. } \\
\text { Patient I, 0.1 ml. + Plasma "W" deficient } \\
\text { in plasma thromboplastin antecedent } \\
\text { (diluted 1/80) } 0.1 \text { ml. }\end{array}$ & $\begin{array}{l}54 \\
12 \\
52\end{array}$ \\
\hline
\end{tabular}

* Clotting time in duplicate at $25^{\circ} \mathrm{C}$. of mixtures of oxalated plasma and $0.025 \mathrm{M}$ calcium chloride solution. $\mathrm{A}, \mathrm{B}$ and $\mathrm{C}$ represent separate experiments. In $\mathrm{A}, 0.2 \mathrm{ml}$. of plasma were mixed with $0.2 \mathrm{ml}$. of calcium chloride solution. In B and C, $0.1 \mathrm{ml}$. of Patient I's plasma was mixed with $0.1 \mathrm{ml}$. of buffer, or a dilution of plasma in buffer, and $0.1 \mathrm{ml}$. of calcium chloride solution.

the more specific method of Owren and Aas (9, 10), was 70 per cent of one normal plasma, and 95 per cent of another. The conversion of prothrombin to thrombin during the clotting of whole blood in Pyrex tubes was tested in Cases I and II. One hour after the blood was drawn, the serum prothrombic activity was 43 and 63 per cent of that of the plasma in Cases I and II, respectively, slightly elevated values.

The presence of the hypocoagulative trait in both sexes makes it unlikely that the patients had either hemophilia or a deficiency of plasma thromboplastin component (Christmas disease) (1618). Table IV illustrates the correction of the defect in Case I by very small amounts of the plasma of patients with each of these disorders. Similar observations were made for hemophilia in Cases II and III, and for Christmas disease, in Case II. In the same manner, plasma from patients thought to have a deficiency of plasma 
thromboplastin antecedent ${ }^{\circ}(19)$ and of a fourth thromboplastin component ${ }^{7}$ (20) corrected the defect in Patients I and II. Similarly, as little as $0.05 \mathrm{ml}$. of oxalated plasma from patients with deficiencies of plasma thromboplastin antecedent or the fourth thromboplastin component shortened the clotting time of $1 \mathrm{ml}$. of Patient II's whole blood to the same degree as $0.05 \mathrm{ml}$. of normal oxalated plasma. One-tenth part of oxalated plasma from Patients I and II were virtually without effect on the clotting time of Patient I's whole blood.

Patient I's defect was corrected in vivo by the transfusion of $250 \mathrm{ml}$. of citrated human plasma. One and a half hours after the transfusion had been completed, the recalcified clotting time was 12 minutes, compared with a pre-transfusion clotting time of 60 minutes; 18 hours after the transfusion the recalcified clotting time was 65 minutes.

Trypsin clots blood or plasma by converting prothrombin to thrombin. It is not clear whether a co-factor is needed. Trypsin clotted the plasma in Case II in the same time as a normal control.

Human plasma is also clotted by staphylocoagulase, a product of certain staphylococci. This process is mediated through a coagulase-reacting factor in plasma. The plasma in Case II was clotted as promptly as a normal plasma by a culture of staphylococci, demonstrating that the patient's plasma contained coagulase-reacting factor.

Preliminary studies suggested that the defect in Case I could be corrected by the addition of the acid-insoluble globulin precipitated from diluted normal plasma at approximately $\mathrm{pH}$ 5.3. This observation made it possible to corroborate the identity of Cases I, II, and III, and to separate these cases from known instances of other hemorrhagic disorders.

One-tenth $\mathrm{ml}$. of oxalated plasma to be tested was pipetted into a Pyrex tube. The acid-insoluble globulin was precipitated by dilution and acidification and dissolved in $0.1 \mathrm{ml}$. of buffer. To this solution was added a volume of $0.5 \mathrm{ml}$. of native plasma from Patient II. The clotting time of the

- Plasmas from A. A. and W., two patients with a deficiency of plasma thromboplastin antecedent, were kindly provided by Dr. R. L. Rosenthal, New York.

I Plasma from C. C., the patient with a deficiency of the fourth thromboplastin component, was kindly provided by Dr. T. Spaet, San Francisco.
TABLE V

The clot-promoting effect of a globulin fraction of oxalated plasma on the native plasma of Patient II

\begin{tabular}{lc}
\hline \multicolumn{1}{c}{ Source of globulin } & $\begin{array}{c}\text { Clotting } \\
\text { time* }\end{array}$ \\
\hline & min. \\
Buffer solution alone & $\infty$ \\
Control plasma, fresh & 2 \\
Control plasma, stored 8 months & 4 \\
Plasma, Case No. 1, stored 12 months & 36 \\
Plasma, Case No. 2, fresh & 48 \\
Plasma, Case No. 3, fresh & 29 \\
Hemophilic plasma, fresh & 4 \\
Hemophilic plasma, stored 10 months & 3 \\
Christmas disease plasma, stored 13 months & 4 \\
Plasma deficient in plasma thromboplastin ante- & 3 \\
cedent, stored 11 days & 2 \\
Plasma deficient in fourth thromboplastin com- & \\
ponent, stored 6 months & 5 \\
Plasma with circulating anticoagulant os. throm- & 5 \\
boplastin, stored 5 months &
\end{tabular}

* Clotting time in Pyrex tubes (internal diameter, 11 mm.) at $37^{\circ} \mathrm{C}$. of mixtures of $0.1 \mathrm{ml}$. globulin solution and $0.5 \mathrm{ml}$. fresh native plasma of Patient II. The patient with a circulating anticoagulant had lupus erythematosis. The stored plasmas had been kept in the frozen state.

mixture was determined at $37^{\circ} \mathrm{C}$., tilting the tubes every 30 seconds.

Representative results of this experiment are listed in Table V. Only the globulin from the three patients under study failed to shorten the clotting time dramatically.

It is of note that plasminogen, which could be activated by streptokinase, was demonstrable in the plasma in Case II.

\section{Some properties of a clot-promoting factor of normal plasma or serum}

The preceding experiments demonstrate that the defect could be corrected by normal plasma or a plasma globulin fraction. A further delineation of the clot-promoting activity of normal blood was attempted. Serum depleted of lipid was as corrective as normal serum. Barium sulfate-adsorbed oxalated normal plasma was almost as effective as unadsorbed oxalated plasma. On the other hand, an eluate of the material adsorbed to the barium sulfate also exhibited some activity. The defect could be corrected by normal oxalated plasma, stored at $4^{\circ} \mathrm{C}$. for 12 weeks, or normal serum, stored at $4^{\circ} \mathrm{C}$. for 6 weeks. The clot-promoting activity in barium sulfate-adsorbed serum resisted heating to $60^{\circ} \mathrm{C}$. for 30 minutes, with some loss, but was destroyed at $70^{\circ} \mathrm{C}$. in $10 \mathrm{~min}$ utes, coincident with gellation of the serum pro- 
teins. Maximal precipitation of the active globulin fraction from diluted serum occurred over a wide range of acidity. No difference in activity was noted in fractions precipitated from $\mathrm{pH} 4.6$ to 5.7. Neither adsorption with barium sulfate nor heating to $56^{\circ} \mathrm{C}$. for 30 minutes induced the appearance of the clot-promoting fraction in the plasma in Case II.

With these data in mind, a crude preparation of the clot-promoting fraction was made by adsorbing pooled serum, which had been stored at $4^{\circ} \mathrm{C}$. for 6 weeks, with powdered barium sulfate. The adsorbed serum was heated at $56^{\circ} \mathrm{C}$. for 30 minutes, centrifuged, and the globulin fraction insoluble at pH 5.3 precipitated. Successive ammonium sulfate-insoluble fractions of this precipitate were then separated. In one such experiment, the greatest part of the clot-promoting activity was precipitated between 33 and 50 per cent saturation with ammonium sulfate, lesser amounts between 25 and 33 per cent, and little or no activity, between 0 and 25 per cent or above 50 per cent. In later studies, it seemed probable that the bulk of the activity was precipitated between 25 and 40 per cent saturation.

A number of tests were performed with this fraction. Even in high dilution it corrected the defect in the plasma in each case. For example, one part of clot-promoting fraction shortened the recalcified clotting time of 80 parts of Patient II's oxalated plasma from 45 minutes to 10 minutes.

The clot-promoting fraction was not thrombic, since it did not clot a solution of bovine fibrinogen. It did not alter the clotting time of a mixture of bovine thrombin and bovine fibrinogen. It prolonged slightly the clotting time of mixtures of bovine thrombin with either fresh plasma or plasma which had been refrigerated at $4^{\circ} \mathrm{C}$. for 12 weeks.

The clot-promoting fraction did not possess appreciable thromboplastic or anti-hemophilic activity. One-sixth part of the fraction did not clot hemophilic platelet-deficient plasma in siliconecoated tubes. In Pyrex tubes, the fraction clotted hemophilic plasma in 150 minutes, but at this time partial clots were also seen in control tubes containing buffer instead of the fraction.

The fraction's lack of thromboplastic activity was also demonstrated by a study of the plasma of a patient with a circulating anticoagulant whose case was described in an earlier report (21). This patient's plasma clotted in a normal time upon the addition of highly diluted human brain thromboplastin. However, its anticoagulant effect was not overcome by a clot-promoting fraction prepared by heating barium sulfate-adsorbed fresh hemophilic plasma to $56^{\circ} \mathrm{C}$. for 30 minutes and then precipitating the globulin fraction insoluble at $\mathrm{pH}$ 5.2.8 Thus the fraction did not behave in the same way as tissue thromboplastin.

The clot-promoting fraction did not alter the one-stage prothrombin time of fresh normal plasma and contained no prothrombin, as determined by the method of Owren and Aas $(9,10)$. By a twostage prothrombin method (11) the fraction did not influence the rate of evolution of thrombin by tissue thromboplastin in diluted plasma. Furthermore, it was without proaccelerin or proconvertin activity. Thus the fraction did not shorten the prolonged prothrombin time of normal plasma which had been stored at $4^{\circ} \mathrm{C}$. for 2 months, and of plasma from a patient under treatment with Dicumarol ${ }^{\circledR}$. This patient's prothrombin time was shortened by a one per cent solution of aged human serum, demonstrating that the plasma was deficient in proconvertin.

None the less, it was possible to demonstrate that the clot-promoting fraction had a profound effect on the conversion of prothrombin to thrombin in shed blood. One part of the fraction, in its original plasma concentration, was incubated for 1 hour at $37^{\circ} \mathrm{C}$. with 8 parts of Patient I's whole blood. At the end of this time, the serum prothrombic activity was 4 per cent of plasma. In contrast, after one hour at $37^{\circ} \mathrm{C}$. the serum prothrombic activity of this patient's blood alone was 43 per cent of plasma.

Similarly, the clot-promoting fraction decreased the serum prothrombic activity of normal blood strikingly. Thus, 20 minutes after 8 parts of blood were incubated at $37^{\circ} \mathrm{C}$. with one part of buffer the serum prothrombic activity was 65 per cent of the prothrombic activity of plasma. On the other hand, 20 minutes after 8 parts of blood were mixed with one part of the fraction, the serum prothrombic activity was less than 10 per cent.

8 This experiment was performed in February, 1950, in association with Dr. R. C. Hartmann and Dr. C. L. Conley. 
Further incubation did not decrease the amount of prothrombin in the serum.

The clot-promoting activity in the crude fraction was only slightly diminished by heating at $60^{\circ} \mathrm{C}$. for 30 minutes. The procedure outlined should not have removed all plasminogen activity. A clot formed from bovine fibrinogen and thrombin, in the presence of streptokinase and the fraction, lysed in 9 minutes; a control in which buffer was substituted for streptokinase did not lyse in 60 minutes.

The possible identity of the clot-promoting fraction with a previously described clotting factor

In a study of the relationship between the proteolytic activity of plasma and blood coagulation, a clot-accelerating property was observed in globulin preparations devoid of known clotting factors (1). These preparations and the clot-promoting fraction deficient in the plasma of the patients under study were made in a similar way. An attempt was made to determine whether these patients lacked the previously described factor.

Duplicating the previously published experiments, the globulin fraction of barium-sulfate adsorbed plasma, heated at $56^{\circ} \mathrm{C}$. for 30 minutes, was prepared from normal plasma and from the plasma of Patient II. As had been reported previously, this globulin fraction of normal plasma accelerated the clotting of normal platelet-deficient plasma in silicone-lined tubes (Table VI). On the other hand, the globulin fraction prepared from the patient's plasma was virtually devoid of this activity. Furthermore, the more highly purified clot-promoting fraction of normal serum, which corrected the defect in the patient's plasma,
TABLE VI

The effect of a globulin fraction prepared from heated, adsorbed, oxalated plasma upon the clotting time of normal native plasma

\begin{tabular}{lcc}
\hline \hline & \multicolumn{2}{c}{ Clotting time* } \\
\cline { 2 - 3 } Concentration of globulin & $\begin{array}{c}\text { Normal } \\
\text { globulin }\end{array}$ & $\begin{array}{c}\text { Patient } \\
\text { II's } \\
\text { globulin }\end{array}$ \\
\hline Original plasma concentration & min. & min. \\
1/2 plasma concentration & 5 & 18 \\
1/4 plasma concentration & 6 & 20 \\
Buffer control & 7 & 24 \\
& 20 &
\end{tabular}

* Clotting time in duplicate at $37^{\circ} \mathrm{C}$. in silicone-coated tubes (internal diameter, $8 \mathrm{~mm}$.) of mixtures of $0.4 \mathrm{ml}$. globulin solution and $0.2 \mathrm{ml}$. normal native plasma. The globulin solutions were prepared from oxalated plasma which had been adsorbed with barium sulfate and heated at $56^{\circ} \mathrm{C}$. for 30 minutes. The globulin solutions were diluted with buffer.

also accelerated the clotting time of normal native plasma. Thus it seems likely that these patients are deficient in the clot-accelerating property described earlier.

The difference between the globulins of normal and abnormal plasmas could be demonstrated not only when the plasmas had been oxalated, adsorbed with barium sulfate, and heated, but also in globulin prepared in silicone tubes from native plasma. In repeated experiments, normal native plasma globulin greatly accelerated the clotting time of normal native plasma. The effect of two such globulins is demonstrated in Table VII. The globulin fraction of Patient II's native plasma, on the other hand, had virtually no clot-promoting effect.

This same experiment was performed, comparing hemophilic and normal plasmas. In both hemophiliacs tested, the clot-promoting effect was

TABLE VII

The effect of native globulin upon the clotting time of normal native plasma

\begin{tabular}{|c|c|c|c|c|c|}
\hline \multirow[b]{2}{*}{ Concentration of globulin } & \multicolumn{5}{|c|}{ Clotting time $(\min .)^{*}$} \\
\hline & $\underset{A}{\text { Normal }}$ & $\underset{B}{\text { Normal }}$ & $\begin{array}{c}\text { Patient } \\
\text { II }\end{array}$ & $\underset{C}{\text { Normal }}$ & Hemophiliac \\
\hline $\begin{array}{l}\text { Original plasma concentration } \\
1 / 2 \text { plasma concentration } \\
1 / 4 \text { plasma concentration } \\
1 / 8 \text { plasma concentration } \\
\text { Buffer control }\end{array}$ & $\begin{array}{r}3 \\
4 \\
5 \\
5 \\
17\end{array}$ & $\begin{array}{r}4 \\
6 \\
8 \\
11 \\
17\end{array}$ & $\begin{array}{l}13 \\
17 \\
18 \\
18 \\
17\end{array}$ & $\begin{array}{r}4 \\
5 \\
8 \\
10 \\
34\end{array}$ & $\begin{array}{r}8 \\
9 \\
11 \\
13 \\
34\end{array}$ \\
\hline
\end{tabular}

* Clotting time of a mixture of $0.4 \mathrm{ml}$. globulin, prepared in silicone-coated tubes from native plasma, and $0.2 \mathrm{ml}$. normal native plasma. The globulin was diluted serially with buffer. Clotting times were measured in duplicate at $37^{\circ} \mathrm{C}$. in silicone-coated tubes (internal diameter, $11 \mathrm{~mm}$.). The normal native plasmas tested with normal globulins $A$ and $B$ and Patient II differed in each case, but normal Globulin $C$ and the hemophilic globulin were tested simultaneously with the same native plasma. 
less than that of normal globulin, although still much greater than that of plasma from Patient II (Table VII). Similar results were obtained testing the globulins prepared from the oxalated plasmas of a normal individual, a hemophiliac, and Patient III simultaneously.

\section{DISCUSSION}

The initiation of clotting in shed human blood has been unravelled in large measure through the study of individuals with one or another hemorrhagic disorder. As a result of such studies, a number of soluble components of plasma have been implicated in the evolution of thromboplastic activity in shed blood. These components include the anti-hemophilic factor (or thromboplastinogen) (2, 22-24), plasma thromboplastin component (or Christmas factor) (16-18), plasma thromboplastin antecedent (19), and a fourth plasma thromboplastin component recently described by Spaet, Aggeler, and Kinsell (20). In addition, there is evidence that prothrombin cannot be converted to thrombin optimally until the plasma or tissue thromboplastin reacts in some manner with proaccelerin (or Factor V, plasma ac-globulin or labile factor) (25) and proconvertin (or serum prothrombin conversion accelerator, Factor VII or co-thromboplastin) (2528) to develop "effective" thromboplastic activity. Platelets may be needed for the development of maximal amounts of effective thromboplastic activity in plasma $(23,27-31)$, but probably not in systems containing tissue thromboplastin.

The three patients described in the present report seem to reveal hitherto unappreciated mechanisms involved in the development of plasma thromboplastic activity. These patients were remarkable in that they all had abnormally long clotting times without apparent ill effects. The long clotting time was the result of a defect in the plasma, since platelet-deficient plasma was incoagulable in glass. This defect was due neither to the presence of a circulating anticoagulant, nor to a deficiency in any of the following clotting factors, namely, fibrinogen, prothrombin, proaccelerin, proconvertin, anti-hemophilic factor, plasma thromboplastin component, plasma thromboplastin antecedent, the fourth thromboplastin component, staphylocoagulase-reacting factor, nor any factors needed for the action of trypsin on prothrombin (32) or for the conversion of fibrinogen to fibrin by thrombin (7). The normal thrombin and prothrombin times suggested that the defect was at an early stage in the clotting process, presumably in the plasma's intrinsic capacity to initiate the conversion of prothrombin to thrombin through some as yet unidentified mechanism. This was confirmed by the slightly increased serum prothrombic activity in Cases I and II, indicative of a defect in the conversion of prothrombin to thrombin.

The unique nature of the patients' abnormality was confirmed by the preparation of a globulin fraction of normal plasma or serum which corrected the defect. The active principle was separated from fibrinogen, anti-hemophilic globulin and proaccelerin by the use of serum instead of plasma, and from prothrombin, proconvertin and plasma thromboplastin component by adsorption of these substances upon barium sulfate. It resisted heating at $60^{\circ} \mathrm{C}$. which is said to inactivate the fourth thromboplastin component (20). The method of preparation was such that one could not be sure that the fraction was devoid of plasma thromboplastin antecedent. However, this substance is said to be present in Cohn fractions III and IV of plasma, but not in fraction II (33). Preliminary studies suggest that both Cohn fractions II and III are effective in correcting the patients' defect.

Moreover, the normal globulin fraction seemed to be active at that stage of the clotting process defective in the abnormal plasmas. The fraction was neither thrombic nor thromboplastic. It did not alter the rate at which fibrinogen was converted to fibrin by thrombin, nor the rate at which prothrombin was converted to thrombin by tissue thromboplastin. However, the fraction tremendously accelerated the rate at which prothrombin was converted to thrombin when either normal or abnormal whole blood was allowed to clot in glass tubes. Thus the fraction was probably concerned with an early step of clotting, presumably the evolution of thromboplastic activity in shed blood.

Since the whole blood clotting time of each patient was prolonged, it is likely that the clot-promoting fraction is necessary for the optimal clotting of blood in vitro. The active globulin frac- 
tion of normal plasma not only corrected the patients' defect, but accelerated the clotting of normal plasma as well. This suggests that the clotpromoting fraction may be present in the form of a precursor which is activated when blood is shed. The manner in which the fraction is activated by the precipitation of the globulin was not clarified. Since the globulin prepared in silicone tubes from normal native plasma was effective, exposure to wettable surfaces or the addition of oxalate was not necessary. The activation was not the result of the dilution which ordinarily takes place during preparation of the globulin, since an active globulin could be prepared by dialyzing serum against a buffer solution of low ionic strength $(0.02)$ at $\mathrm{pH} 5.5$, without any change in volume. Moreover, in incomplete experiments, a mixture of the precipitated globulin recombined with the supernatant dialyzed plasma still possessed clot-promoting activity. Both dilution and dialysis greatly reduce the concentration of many dialyzable components of the plasma, but simple dialysis of serum against barbital-saline buffer at $\mathrm{pH} 7.5$ did not appear to activate the clot-promoting fraction.

The means by which the clot-promoting fraction influenced the development of thromboplastic activity were not defined. It was of interest that hemophilic native globulin was less effective than the normal in shortening the clotting time of normal native plasma, even though hemophilic plasma contained the same amount of the clot-promoting fraction as normal plasma. One hypothesis, then, is that the clot-promoting fraction exerts its action in association with the anti-hemophilic factor. This would be compatible with the observation that the clot-promoting fraction did not significantly alter the clotting time of native hemophilic plasma. Further experiments to test this hypothesis are in progress.

The bulk of the experiments reported refer to phenomena observed in vitro. It is noteworthy that the transfusion of normal plasma corrected the defect in Patient I. However, within 16 hours, his clotting time was once more abnormal. Thus in this patient the clot-promoting fraction seemed to have been utilized or destroyed rapidly.

The stability and solubility characteristics of the clot-promoting fraction are such that one would expect that its effect had been observed and recorded by other investigators. The frac- tion has many features in common with an accelerator of clotting, described in an earlier study, which seemed responsible for the clot-promoting effect of crude preparations of plasmin (1). Milstone $(34,35)$ has described a fraction of bovine globulin which had been adsorbed with barium sulfate. This fraction, when incubated with calcium ions, was activated to form a complex, named thrombokinase, which converted prothrombin to thrombin. Its method of preparation was such that it may well have been rich in the clotpromoting fraction described in the present paper. Tocantins, Carroll, and Holburn (36) observed that a euglobulin preparation of hemophilic plasma accelerated the clotting of normal blood. Although their interpretation differed, it is possible that these experiments can be explained by the presence of the clot-promoting fraction. Similarly, Nolf (37), Lenggenhager (38), Feissly (39), Travis and Ferguson (40) and others have described clot-enhancing preparations of plasma the activity of which may be partially explained by their content of the clot-promoting fraction.

The scientific literature dealing with problems of blood coagulation has been confused by a nomenclature which is complex and conflicting. It seems unwise to name the clot-promoting fraction described in the present report, or the trait manifest by its absence, until more is known of its mechanism of action. Temporarily one may designate the fraction by the name of Patient $I$, as Hageman factor, and its deficiency, as Hageman trait. The fraction is under continued, intensive study. Finally, it is noteworthy that it is possible to have a prolonged clotting time for many years without obvious harm, and in spite of operative procedures, childbirth, and menses. Presumably, the hemostatic mechanisms are such that they can protect these patients from injury. How these mechanisms operate to overcome the defect in coagulation is yet to be determined.

\section{SUMMARY}

1. A familial trait, occurring in both sexes, characterized by a prolonged clotting time without significant hemorrhagic symptoms, is described. The prolonged clotting time was apparently due to a defect in the production of plasma thromboplastic activity in shed blood. 
However, the trait could not be identified with known hemorrhagic disorders.

2. A clot-promoting fraction apparently distinctive from known clotting factors could be prepared from normal barium sulfate-adsorbed, heated serum. This fraction not only corrected the defect in the patient's plasma but shortened the clotting time of normal platelet-deficient plasma. Data are presented relative to the significance of this clot-promoting fraction.

\section{ACKNOWLEDGMENTS}

Patients I and II were studied through the courtesy of Dr. N. Shumway, Crile V. A. Hospital, and Dr. J. Hewlett, the Cleveland Clinic, respectively. Miss Joanne Hutchinson did the tests for staphylocoagulase-reacting factor. Delipidization of serum was performed in collaboration with Dr. Saul Korey.

\section{REFERENCES}

1. Ratnoff, O. D., Hartmann, R. C., and Conley, C. L., Studies on a proteolytic enzyme in human plasma. V. The relationship between the proteolytic activity of plasma and blood coagulation. J. Exper. Med., 1950, 91, 123.

2. Conley, C. L., Hartmann, R. C., and Morse, W. I., II, The clotting behaviour of human "plateletfree" plasma: evidence for the existence of a "plasma thromboplastin." J. Clin. Invest., 1949, 28, 340 .

3. Ratnoff, O. D., and Conley, C. L., The role of surface and of calcium in the coagulation of a globulin fraction of platelet-deficient plasma. Bull. Johns Hopkins Hosp., 1951, 89, 245.

4. Lee, R. I., and White, P. D., A clinical study of the coagulation time of blood. Am. J. M. Sc., 1913, $145,495$.

5. Ratnoff, O. D., Colopy, J. E., and Pritchard, J. A., The blood-clotting mechanism during normal parturition. J. Lab. \& Clin. Med., 1954, 44, 408.

6. Conley, C. L., Hartmann, R. C., and Morse, W. I., II, Circulating anticoagulants: a technique for their detection and clinical studies. Bull. Johns Hopkins Hosp., 1949, 84, 255.

7. Ratnoff, O. D., An accelerating property of plasma for the coagulation of fibrinogen by thrombin. J. Clin. Invest., 1954, 33, 1175.

8. Quick, A. J., Stanley-Brown, M., and Bancroft, F. W., A study of the coagulation defect in hemophilia and jaundice. Am. J. M. Sc., 1935, 190, 501.

9. Alexander, B., Coagulation of Blood. Methods of Study. National Research Council. L. Tocantins, Ed., Grune and Stratton, Co., N. Y., In press.

10. Owren, P. A., and Aas, K., The control of Dicumarol therapy and the quantitative determination of prothrombin and proconvertin. Scandinav. J. Clin. \& Lab. Invest., 1951, 3, 201.

11. Ware, A. G., and Seegers, W. H., Two-stage procedure for the quantitative determination of prothrombin concentration. Am. J. Clin. Path., 1949, 19, 471.

12. Ware, A. G., Guest, M. M., and Seegers, W. H., Fibrinogen: with special reference to its preparation and certain properties of the product. Arch. Biochem., 1947, 13, 231.

13. Cadness-Graves, B., Williams, R., Harper, G. J., and Miles, A. A., Slide-test for coagulase-positive staphylococci. Lancet, 1943, 1, 736.

14. Christensen, L. R., Methods for measuring the activity of components of the streptococcal fibrinolytic system, and streptococcal desoxyribonuclease. J. Clin. Invest., 1949, 28, 163.

15. Seegers, W. H., and Smith, H. P., Factors which influence the activity of purified thrombin. Am. J. Physiol., 1942, 137, 348.

16. Aggeler, P. M., White, S. G., Glendening, M. B., Page, E. W., Leake, T. B., and Bates, G., Plasma thromboplastin component (PTC) deficiency: A new disease resembling hemophilia. Proc. Soc. Exper. Biol. \& Med., 1952, 79, 692.

17. Schulman, I., and Smith, C. H., Hemorrhagic disease in an infant due to a deficiency of a previously undescribed clotting factor. Blood, 1952, 7, 794.

18. Biggs, R., Douglas, A. S., Macfarlane, R. G., Dacie, J. V., Pitney, W. R., Merskey, C., and O'Brien, J. R., Christmas disease. A condition previously mistaken for haemophilia. Brit. Med. J., 1952, 2, 1378.

19. Rosenthal, R. L., Dreskin, O. H., and Rosenthal, N., New hemophilia-like disease caused by deficiency of a third plasma thromboplastin factor. Proc. Soc. Exper. Biol. \& Med., 1953, 82, 171.

20. Spaet, T. H., Aggeler, P. M., and Kinsell, B. G., A possible fourth thromboplastin component. J. Clin. Invest., 1954, 33, 1095.

21. Conley, C. L., Ratnoff, O. D., Ellicott, C. E., and Hartmann, R. C., Studies on the initiation of blood coagulation. II. An anticoagulant inhibiting the activation of a plasma thromboplastic factor. J. Clin. Invest., 1950, 29, 1182.

22. Patek, A. J., Jr., and Stetson, A. R., Hemophilia. I. The abnormal coagulation of the blood and its relation to the blood platelets. J. Clin. Invest., 1936, 15, 531.

23. Lozner, E. L., and Taylor, F. H. L., The effect of foreign surfaces on blood coagulation. J. Clin. Invest., 1942, 21, 241.

24. Quick, A. J., Studies on the enigma of the hemostatic dysfunction of hemophilia. Am. J. M. Sc., 1947, 214, 272.

25. Flynn, J. E., and Coon, R. W., Purification and isolation of certain intermediates formed prior to the activation of prothrombin. Am. J. Physiol., 1953, 175, 289. 
26. Mann, F. D., and Hurn, M. M., The complex mechanisms of the Quick prothrombin test and the effect of Dicumarol. Am. J. Clin. Path., 1950, 20, 225.

27. Biggs, R., and Douglas, A. S., The thromboplastin generation test. J. Clin. Path., 1953, 6, 23.

28. Fiala, S., and Roth, K., Platelets and the thromboplastic system of blood coagulation. Arch. internat. de physiol., 1953, 61, 205.

29. Brinkhous, K. M., Clotting defect in hemophilia. Deficiency in a plasma factor required for platelet utilization. Proc. Soc. Exper. Biol. \& Med., 1947, 66, 117.

30. Van Crevald, S., and Paulssen, M. M. P., Isolation and properties of the third clotting factor in bloodplatelets. Lancet, 1952, 1, 23.

31. Johnson, S. A., Smathers, W. M., and Schneider, C. L., Platelets and their plasma cofactor activity in the activation of purified prothrombin. Am. J. Physiol., 1952, 70, 631.

32. Lenggenhager, $K$., Einige Klärungen in der Blutgerinnungsfrage. Schweiz. med. Wchnschr., 1946, 76, 410.
33. Rosenthal, R. L., Properties of plasma thromboplastin antecedent (PTA) in relation to blood coagulation. J. Lab. \& Clin. Med., 1955, 45, 123.

34. Milstone, J. H., Three-stage analysis of blood coagulation. J. Gen. Physiol., 1948, 31, 301.

35. Milstone, J. H., Fractionation of plasma globulin for prothrombin, thrombokinase and accessory thromboplastin. J. Gen. Physiol., 1951, 35, 67.

36. Tocantins, L. M., Carroll, R. T., and Holburn, R. H., The clot accelerating effect of dilution of blood and plasma. Relation to the mechanism of blood coagulation in normal and hemophilic blood. Blood, 1951, 6, 720.

37. Nolf, P., The coagulation of the blood. Medicine, 1938, 17, 381.

38. Lenggenhager, $K$., Irrwege der Blutgerinnungsforschung. Klin. Wchnschr., 1936, 15, 1835.

39. Feissly, R., Sur l'activateur plasmatique de la prothrombine; facteur indépendent des protéases du plasma. Schweiz. med. Wchnschr., 1943, 73, 925.

40. Travis, B. L., and Ferguson, J. H., Proteolytic enzymes and platelets in relation to blood coagulation. J. Clin. Invest., 1951, 30, 112. 